http://jmscr.igmpublication.org/home/

ISSN (e)-2347-176x ISSN (p) 2455-0450

crossref DOI: https://dx.doi.org/10.18535/jmscr/v7i7.168

Journal Of Medical Science And Clinical Research

\title{
A comparative study on the effects of short term Pranayama on Pulmonary function test
}

\author{
Authors \\ Romita Potsangbam ${ }^{1}$, Mayanglambam Sangeeta Devi ${ }^{2 *}$, Deben Singh Laishram ${ }^{3}$ \\ ${ }^{1}$ Assistant Professor, Department of Physiology, JNIMS, Porompat \\ ${ }^{2}$ Assistant Professor, Department of Physiology, JNIMS, Porompat \\ ${ }^{3}$ Professor, Department of Physiology, JNIMS, Porompat \\ *Corresponding Author \\ Dr Mayayanglambam Sangeeta Devi \\ Assistant Professor, Department of Physiology, JNIMS, Porompat
}

\begin{abstract}
Background: Pranayama brings the conscious awareness of breathing and helps to reshape breathing habits and patterns. The persistent conditioning of the breathing patterns in pranayama increases the pulmonary function in healthy individuals and increases the overall performance of an individual.

Method: The present study was conducted in the department of Physiology, JNIMS. A total of 25 healthy males within the age group of 25 to 25 working in the preclinical department of JNIMS were taken into the study. The volunteers were given pranayama practice for 30 minutes daily under the supervision of a trained yoga instructor for a duration of two months. Pulmonary function parameters such as Forced Vital Capacity (FVC), Forced Expiratory volume in $1^{\text {st }}$ second (FEV1\%), Peak Expiratory Flow Rate (PEFR), FEF 25\%, Slow Vital Capacity(SVC) and Maximum Voluntary Ventilation( MVV) were assessed before and after two months of yoga training by using Medicaid Spiro Excel PC based Pulmonary Function system. The data was processed through SPSS version 22 to find any significant association.

Result: Forced Vital Capacity (FVC), Forced Expiratory volume in $1^{\text {st }}$ second (FEV1\%), Peak Expiratory Flow Rate (PEFR), FEF 25\%, Slow Vital Capacity(SVC) and Maximum Voluntary Ventilation( MVV) were found to be significantly increased after 2 months of short term pranayama.

Conclusion: These beneficial effects of pranayama can also be used in daily practice as a part of physical fitness and lifestyle modification programmes in maintaining physical and mental health as well as an adjunct therapy for many respiratory disease.

Keywords: pranayama, pulmonary function test, FVC, FEV1\%, PEFR, FEF 25\%, SVC and MVV.
\end{abstract}

\section{Introduction}

Yoga is a Sanskrit word which means "union': union of the mind, body and spirit - the union between us and the intelligent cosmic spirit of creation- "the oneness of all things ${ }^{[1]}$. Yoga balances all aspects of life (the physical, mental, emotional, psychic and spiritual) and harmonize the body, mind and emotions ${ }^{[2]}$. The five principles of yoga are relaxation, exercise (asanas), pranayama (breathing control), nourishing diet, positive thinking and medication $^{[3]}$. Breath is the dynamic bridge between body and mind and pranayama (breathing techniques) is one of the most important yogic practices which can produce different physiological response in healthy individuals ${ }^{[4,5]}$. 
Pranayama literally "control of prana". Prana meaning life force or life energy: Yama discipline or control and Ayama - expansion or non-restraint or extension ${ }^{[6]}$. Through pranayama, one uses the breath to affect the constellation of energy that is your body and mind. Pranayama is an art of prolongation and control of breath which helps to bring the conscious awareness in breathing; to reshape breathing habits and patterns. The persistant conditioning of breathing patterns of pranayama increases the pulmonary function in healthy individuals and increases the overall performance of the body ${ }^{[5]}$. The regular practice of prayanama increases chest wall expansion and almost all lung functions and makes efficient use of abdominal and diaphragmatic muscles and improves the respiratory apparatus ${ }^{[7]}$.

Yoga respiration consist of slow, deep breaths with sustained breathhold after each inspiration and practicing yoga contributes in the improvement of pulmonary ventilation and gas exchange $^{[8]}$.

Pulmonary function are generally determined by the strength of the respiratory muscles, compliance of the thoracic cavity, airway resistance and elastic recoil of the lungs ${ }^{[9]}$

Pulmonary function test serves as a tool of health assessment and also to some extend as a predictor of survival rate and tends to have a relationship with life style such as regular exercise and nonexercise $^{[10]}$. It also provides a qualitative and quantitative assessment of pulmonary function in patients of restrictive and obstructive lung diseases. The test used to describe pulmonary function are the lung volume and lung capacities. It is well known that pulmonary functions may vary according to the physical characteristics including age, height, body, weight and altitude. The practice of yoga is accompanied by a number of beneficial physiological effects in the body. Regular practice of yoga is known to improve overall performance and working capacity ${ }^{[11]}$. Current evidence suggest that following regular practice of yoga there is an improvement in cardiovascular and pulmonary functions ${ }^{[12] .}$ The present study plans to assess the effects of pranayama on various pulmonary function by comparing the changes in the lung function before and after pranayama practice.

\section{Materials and Methods}

A total of 25 healthy volunteers who are staffs of the preclinical departments of JNIMS within the age group of 25 to 45 years were taken into the study. The study was conducted in the department of Physiology, JNIMS. The study protocol was approved by the institutional ethical committee. The study was explained to all the volunteers and written informed consent was taken. The subjects were recruited by the following criteria:

Inclusion Criteria: age group between 25 to 45 years, working in the preclinical department of JNIMS.

Exclusion Criteria: subjects with the habits tobacco chewing, smoking and alcoholism, history of systemic diseases including respiratory tract diseases within the previous 6 weeks, history of medication of any diseases or practicing any form of yoga/sports/ exercise etc.

The volunteers were given pranayama practice for 30 minutes daily under the supervision of a trained yoga instructor for a duration of two months.

The following Pranayama, Nadisuddi, Kapalbhati, Bhastrika, Bramhari Pranava Pranayama and Surya Namsakar were practiced for 5 minutes each daily for two months.

Pulmonary function parameters such as Forced Vital Capacity (FVC), Forced Expiratory volume in $1^{\text {st }}$ second(FEV1\%), Peak Expiratory Flow Rate (PEFR), FEF 25\%, Slow Vital Capacity(SVC) and Maximum Voluntary Ventilation( MVV) were assessed before and after two months of yoga training by using Medicaid Spiro Excel PC based Pulmonary Function system.

The data was processed through SPSS version 22 where descriptive statistics like mean, median standard deviation were applied and statistical analysis including t-test and chi square test were applied wherever applicable. 


\section{Results and Observation}

Table 1: Effect of Pranayama on Pulmonary Function test parameters

\begin{tabular}{|l|c|c|c|}
\hline Parameters & $\begin{array}{c}\text { Before } \\
(\text { mean } \pm \text { SD) }\end{array}$ & $\begin{array}{c}\text { After } \\
(\text { mean } \pm \text { SD) }\end{array}$ & P-value \\
\hline FVC (L) & $2.54 \pm 0.52$ & $2.95 \pm 0.49$ & $0^{*}$ \\
\hline FEV1(\%) & $2.19 \pm 0.41$ & $2.60 \pm 0.45$ & $0^{*}$ \\
\hline PEFR (L/min) & $5.28 \pm 1.16$ & $5.88 \pm 1.03$ & $0.017^{*}$ \\
\hline FEF 25\% & $5.07 \pm 1.20$ & $5.57 \pm 1.05$ & $0.05^{*}$ \\
\hline SVC (L) & $2.31 \pm 0.87$ & $2.50 \pm 0.78$ & $0.048^{*}$ \\
\hline MVV(L/min) & $72.18 \pm 5.03$ & $78.22 \pm 5.40$ & $0^{*}$ \\
\hline
\end{tabular}

$*$ P-value $<0.05$ significant

Table 1 shows that there is significant increase in the FVC(L), FEV1(\%), PEFR(L/min), FEF25\%, $\mathrm{SVC}(\mathrm{L})$ and $\mathrm{MVV}(\mathrm{L} / \mathrm{min})$ in the study group following practice of two months of Pranayama.

\section{Discussion}

In the present study we studied the effect of short term Pranyama on Pulmonary function test parameters like FVC(L), FEV1(\%), PEFR(L/min), FEF25\%, SVC(L) and MVV(L/min) of the age and sex matched subjects. We found a significant increase in all the parameters. Our study was consistent with other findings of Udupa $\mathrm{KN}$ et al; Gopal KS et al who reported significant increase in MVV, PEFR and $\mathrm{FVC}^{[13-14]}$. Josie et $\mathrm{al}^{[3]}$ reported significant increase in FVC, FEV1, PEFR, and MVV following 6 weeks of pranayama practice in 75 subjects. There was no change in pulmonary function which was against our finding. However, the sample size was small, all males, short pranayama duration and the lack of a control group could have affected the result.

During pranayama, there is slow and prolonged inspiration and expiration which stretches elastin and collagen fibres interwoven among lung parenchyma and these fibers elongates to a greater extent. Lung inflation near to TLC is a major stimulus for release of lung surfactant into alveolar spaces which increases the lung compliance $^{[15-16]}$. The increase in PEF, FEF25\% and MVV may attribute to voluntary prolongation of inspiration and expiration, during pranayama the respiratory muscles are stretched to their full extent and the respiratory apparatus are able to work to their maximal capacity. Improvement of respiratory muscle function helps to reduce the relative load on the muscles and increase maximal sustained ventilator capacity ${ }^{[17]}$.

During pranayama training, regular inspiration and expiration for longer duration would lead to acclimatization of central and peripheral chemoreceptors for both hypercapnoea and hypoxia. Acclimatization of the stretch receptors increase the synchronization between the lung tissue and the cortex ${ }^{[18]}$. With the regular practice of breath holding, the individual's central and peripheral chemoreceptors gets adapted to the anoxia, this results is achieved by the body by causing hypometabolism ${ }^{[19]}$. By practicing pranayama, the various reflex mechanisms that control respiratory center in bulbopontine area may be altered or modified by producing a strong cortical force thereby increasing the breath holding time on decreasing the resting respiratory rate $^{[20]}$.

\section{Conclusion}

From the present study we may conclude that the pranayama practice can be advocated to improve the pulmonary functions in healthy individuals and hence help to prevent respiratory diseases in future. These beneficial effects of pranayama can also be used as an adjunct therapy for many respiratory disease. The daily practice could also be parts of physical fitness and lifestyle modification programmes in maintaining physical and mental health.

\section{Reference}

1 Ruprai Reena Kaur,et al. Effect of yoga training on breathing rate and lung functions in patients of bronchial asthma. International Journal of Recent Trends in Science and Technology. 2013; 5(3):12729.

2 Saraswati SS. Introduction to Yoga. In: Saraswati SS, editor. Asana Pranayama M Publication Trust; 2008.1-5.

3 LN Josie, VD Josie, LV Gokhale. Effect of of short term Pranayama on Ventilatory 
functions of lungs. Indian $\mathrm{J}$ Physiol Pharmacol. 1992; 36:105-08.

4 Ankad RB, Herur A, Patil S, Shashikala GV, Chinagudi S. Effect of short-term pranayama and meditation on cardiovascular functions in healthy individuals. Heart Views. 2011; 12: 58-62.

5 Patil YR, Sawant RS. Effect of bastrika pranayama on pulmonary function. Int $\mathrm{J}$ Pharm.2012;3:204-7.

6 Biggs Tony, A Watts,lessons Breathing, M Addy. A longtime I yengar Yoga teacher tells you why you should be holding your breath. Yoga journal. 2000; 11/12: 94.

7 NK Subbalakshmi, SK Saxena, Urmimala, JA Urban. Immediate effect of nadishodhana pranayama on some selected parameters of cardiovascular, pulmonary and higher functions of brain. Thai Journal of Physiological Sciences.2005;18(2):1016.

8 Adanmohan, Udupa K, Bhavanani $\mathrm{AB}$, Vijayalakshmi P, Surendiran A. Effect of slow and fast pranayama on reaction time and cardiorespiratory variables. Indian $\mathrm{J}$ Physiol Pharmacol 2005;49:313-8.

9 Cotes JE. Lung Function: Assessment and Applications in Medicine. $4^{\text {th }}$ Edition. Oxford: Blackwell Scientific publication; 1979.

10 Vedala SR, Mane AB, Paul CN. Pulmonary functions in yogic and sedentary population. Int J Yoga 2014;july 24;7:155-9.

11 Madanmohan, Udupa K, Bhavani AB, Shatapathy CC, Sahai A. Modulation training of cardiovascular response to exercise by yoga training. Indian J Physiol Pharmacol 2004;48:461-5.

12 Bera TK, Rajapurkar MV. Body composition, cardiovascular endurance and anaerobic power of yogic practitioner. Indian J Physiol Pharmacol 1993;37:2258.
13 Udupa KN, Singh RM, Shettiwar RH, Singh MB, Physiological changes following some yogic and nonyogic exercises. Ind J. fed Res 1975:10(2);91-96.

14 Gopal KS, Bhamagar OP, Subramanian N. Nisihith SD. Effects of yogasanas and pranayama practice on blood pressure, pulse rate and some respiratory function test. Indian journal Physiol Pharmacol. 1973;17;273-276 .

15 BKS Iyengar London: Geovge Allen and Unwin Ltd; 1968: Light on Yoga, PP 24345

16 LN Josie, VD Josie, LV Gokhale. Effect of short term pranayama on ventilatory functions of lung. Indian $\mathbf{J}$ Physiol Pharmacol. 1992;36:105-08)

17 .)(Nayar HS, Mathur RM, Kumar RS. Effects of yogic exercises on human physical efficiency. Indian J Med Res 1975; 63:1369-76.

18 LN Joshie, VD Josie. Effect of forced breathing on the ventilator function the lung. J Postgraduate Med. 1998;44(3): 6769).(MR Bhargava, MG Gogate. A study of BHJ and its variations following pranayamic exercises. The clinician. 1982: 43-46

19 Amte et al .clinical effects of pranayama on performance of rifle shooters. Intl $\mathrm{J}$ Med Res Health Sci. 2014; 3(3):580-86).

20 Bhargava R, Gogate MG, Mascarenhas JF. Autonomic responses to breathing holding and its variations following pranayama. Indian J Physiol Pharmacol 1988; 32:25764. 